\title{
Evaluasi Deteksi Berbasis PCR untuk Bakteri Bifidobacterium longum dalam Sampel Feses Bayi dari Kota Manado
}

\author{
Beivy Jonathan Kolondam ${ }^{1 *)}$ \\ 1) Jurusan Biologi, Fakultas Matematika dan Ilmu Pengetahuan Alam, Universitas Sam Ratulangi, \\ Manado 95115 \\ *Corresponding author: beivy.kolondam@unsrat.ac.id
}

(Article History: Received 24-01-2020; Accepted 06-04-2020; Published 06-04-2020)

\begin{abstract}
ABSTRAK
Bifidobakteria merupakan mikroflora yang umum hidup dalam usus manusia sejak bayi. Peran Bifidobacterium longum yang positif sebagai salah satu bakteri yang menunjang kesehatan inangnya membuat bakteri ini menjadi objek studi yang menarik. Salah satu instrumen dalam penelitian adalah adalah metode deteksi bakteri B. longum yang berbasis PCR (Polymerase Chain Reaction) gen 16S rRNA. Dengan mempertimbangkan bahwa perancangan primer untuk deteksi ini sudah lebih dari 20 tahun, penelitian ini bertujuan mengevaluasi hasil deteksi melalui PCR terhadap B. longum dalam feses bayi. Akurasi hasil dilihat melalui sekuensing terhadap hasil PCR sampel yang terdeteksi positif. Dua sampel feses bayi di Manado yang diperiksa menunjukkan hasil positif dan produk PCR tersebut dilakukan sekuensing. Panjang DNA yang nyata dari hasil deteksi ini yaitu 829 bp dan bukan 831 bp. Sekuens DNA kedua sampel ini identik satu sama lain. Hasil BLAST (Basic Local Alignment Search Tool) mengonfirmasi kesamaan 100\% (identik) dari kedua specimen dari Kota Manado dengan sekuens gen 16S rRNA specimen bakteri B. longum yang telah ada dalam GenBank.
\end{abstract}

Kata-kata kunci: Bifidobacterium longum, Polymerase Chain Reaction, deteksi, feses, bayi.

\section{Evaluation of PCR-Based Detection for Bifidobacterium longum in Infant Fecal Samples from Manado City}

\begin{abstract}
Bifidobacteria are common members of the gut microflora of humans since infant. The Bifidobacterium longum has positive roles and one of supportive bacteria to the host, which made interesting as a study object. One instrument in studying this bacterial species is the detection method based on PCR of $16 \mathrm{~S}$ rRNA gene. In consideration of the design of primers for this detection method is already more than 20 years, this research aimed to evaluate the PCR-based detection of $B$. longum in infant feces. The accuracy of the method was evaluated from sequencing of DNA fragment from positive results. Two fecal samples in Manado City shown positive result were sent for sequencing. The actual length of DNA amplified by PCR was $829 \mathrm{bp}$, not $831 \mathrm{bp}$. The DNA sequence of both samples were identical to each other. The BLAST (Basic Local Alignment Search Tool) result confirmed the similarity of both samples from Manado with 16S rRNA gene sequence of B. longum specimens in GenBank.
\end{abstract}

Keywords: Bifidobacterium longum, Polymerase Chain Reaction, detection, feces, infant. 


\section{PENDAHULUAN}

Bifidobakteria merupakan penghuni alami dari saluran pencernaan manusia yang telah ada dalam usus sejak bayi (Ventura et al., 2012). Golongan bakteri ini memiliki peran positif untuk menunjang kesehatan inangnya (Tojo et al., 2014). Meskipun demikian, mekanisme ini belum diketahui secara jelas. Untuk itulah maka berbagai studi tentang genom bakteri ini selalu dilakukan (Motherway et al., 2011). Meski terdapat perbedaan prevalensi dari masing-masing spesies Bifidobakteria, Bifidobacterium longum subsp. longum tersebar secara luas dalam usus orang dewasa, manula dan juga pada bayi yang baru lahir (Turroni et al, 2009; Gavini et al., 2001).

Dengan dirancangnya primer-primer PCR yang spesifik untuk berbagai jenis Bifidobakteria oleh Matsuki et al. (1999), termasuk untuk B. longum, proses deteksi dan identifikasi bakteri ini sangat mendukung penelitian-penelitian ekologi mikroba, nutrisi dan klinis (Hernández-Rodríguez et al., 2018; Oki et al., 2018). Perancangan primer tersebut berbasis pada gen 16S rRNA sebagai target. Deteksi dan identifikasi Bifidobakteria menggunakan primer-primer ini sangat bermanfaat karena $B$. longum adalah salah satu dari enam spesies yang secara umum sebagai mikroflora usus (Temmerman et al., 2004).

Mempertimbangkan bahwa perancangan primer ini sudah lebih dari 20 tahun sejak dipublikasikan, maka penelitian ini bertujuan untuk melakukan evaluasi sederhana dari deteksi atau diagnostik PCR terhadap Bifidobacterium longum dalam feses bayi. Dalam studi ini diuji keakuratan metode yang dirancang primernya oleh Matsuki et al. (1999) yang sudah banyak digunakan dalam penelitian. Spesimen feses diambil dari bayi di Kota Manado, Provinsi Sulawesi Utara. Akurasi metode diagnostik ini dilihat dengan melakukan sekuensing terhadap hasil PCR yang dianggap positif.

\section{METODE PENELITIAN}

\section{Koleksi Sampel dan Isolasi DNA Total}

Dua sampel feses diambil dari dua bayi (berusia 30 hari) di Kota Manado menggunakan spatula steril dan dimasukkan ke dalam tabung Falcon $15 \mathrm{ml}$. Sampel ini segera dipreservasi dengan didinginkan selama 6 jam dalam lemari es $\left(4^{\circ} \mathrm{C}\right)$ sebelum proses isolasi DNA. Isolasi DNA total dari sampel feses dilakukan menggunakan UltraClean Fecal DNA Isolation Kit (Mo Bio Laboratories, Inc.) sesuai petunjuk manual.

\section{Polymerase Chain Reaction (PCR) dan Elektroforesis}

Proses PCR dilakukan menggunakan MyTaq $^{\text {TM }}$ HS Red Mix (Bioline). Pasangan primer yang digunakan dalam primer ini berdasarkan Matsuki et al. (1999) yaitu BiLON-1 (5'-ttc cag ttg atc gca tgg tc-3') and BiLON-2 (5'-ggg aag ccg tat ctc tac ga-3'). Reaksi PCR sebanyak 50 ul terdiri atas komponen 25 ul 2x MyTaq $^{\mathrm{TM}}$ HS Red Mix, $1,5 \mathrm{ul}$ masing-masing primer $(10 \mathrm{uM}), 20 \mathrm{ul}$ Milli-Q water steril, dan 2 ul DNA total sampel.

Pengaturan panas mesin PCR menggunakan suhu penempelan primer yang sama dengan Matsuki et al. (1999), dengan perubahan sesuai rekomendasi manual kit PCR yang digunakan. Pemanasan dimulai dengan denaturasi awal $95^{\circ} \mathrm{C}$ (3 menit) dan dilanjutkan dengan 35 siklus denaturasi $95^{\circ} \mathrm{C}$ (15 detik), perlekatan primer $55^{\circ} \mathrm{C}$ (20 detik) dan pemanjangan DNA $72^{\circ} \mathrm{C}$ (20 detik). Untuk pemanjangan akhir digunakan suhu $72^{\circ} \mathrm{C}$ (1 menit).

Hasil PCR diseparasi menggunakan electroforesis gel agarosa $1 \%$. Sebanyak $10 \mathrm{ul}$ produk PCR sampel dan juga DNA ladder 1 kb dengan jumlah yang sama dimasukkan ke dalam sumur-umur gel dan kemudian dialiri arus listrik 100 volt selama 30 menit. Gel direndam dalam cairan yang mengandung etidium bromide selama 10 menit dan diamati keberadaan pita DNA tunggal dengan panjang 831 bp, sesuai Matsuki et al. (1999), dalam gel agarosa. Pita DNA ini berada di antara pita DNA standar berukuran 750 bp dan 1000 bp.

\section{Sekuensing DNA}

Pita DNA hasil PCR dilakukan sekuensing dua arah. Sekuensing dilakukan menggunakan masing-masing primer PCR di First Base C.O. (Malaysia). Kromatogram hasil sekuensing disunting menggunakan piranti lunak Geneious 5.6 (Drummond et al., 2012) yang diawali dengan menggabungkan hasil sekuensing dari kedua primer menggunakan algoritma MUSCLE (Edgar, 2004). Penyuntingan dilanjutkan dengan 
menentukan area penempelan primer di daerah 5' dan 3' sekuens. Sekuens DNA di antara area penempelan primer ini digunakan untuk identifikasi (Kolondam, 2015). Sekuens DNA yang sudah bersih ini dibandingkan kesamaanya dengan semua sekuens yang ada dalam Genbank melalui Basic Local Alignment Search Tool (Altschul et al., 1990) atau BLAST yang tersedia secara daring (www.ncbi.nlm.nih.gov).

\section{HASIL DAN PEMBAHASAN}

\section{Elektroforesis Gel Agarosa dari Hasil PCR}

Deteksi keberadaan bakteri B. longum dari sampel feses menunjukkan keduanya memberikan hasil deteksi positif. Ini terlihat dari munculnya pita yang berukuran antara 750 bp dan 1000 bp (Gambar 1) dari perbandingannya dengan DNA standar $1 \mathrm{~kb}$ yang digunakan.

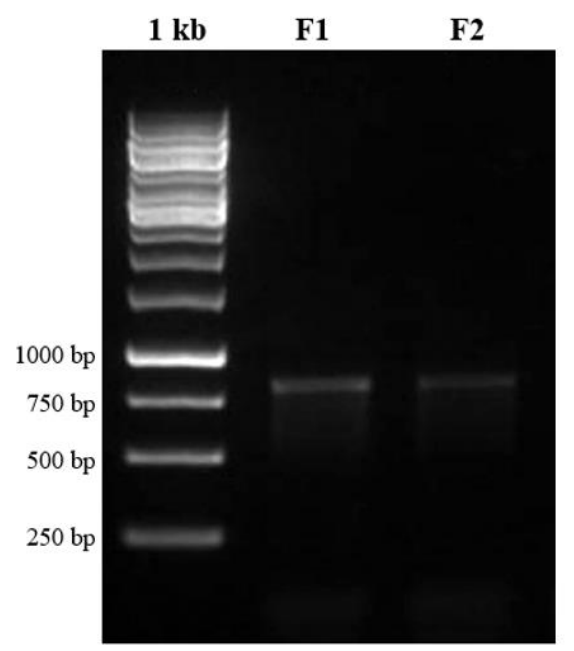

Gambar 1. Elektroforesis gel agarosa $1 \%$ hasil PCR untuk deteksi Bifidobacterium longum

Hal ini sesuai dengan panjang yang diharapkan dalam Matsuki et al. (1999) yang merancang bahwa hasil PCR yaitu berupa pita DNA tunggal berukuran 831 bp untuk dikategorikan sebagai hasil diagnostik positif. Pita yang dihasilkan berupa pita tunggal yang jelas dari dokumentasi elektroforesis gel agarosa.

\section{Evaluasi Panjang Pita DNA Hasil PCR}

Konfirmasi keakuratan diagnostik PCR dalam penelitian ini salah satunya dilakukan dengan melihat sekuens pita DNA yang berhasil diamplifikasi (amplikon) melalui PCR. Kedua sampel DNA telah disunting sekuens DNAnya berdasarkan kualitas kromatogram. Daerah penempelan primer (diberi label "forward primer region" dan "reverse primer region") telah ditentukan lebih dahulu untuk kemudian ditentukan daerah di antara kedua primer tersebut yang akan digunakan untuk identifikasi sekuens secara molekuler melalui GenBank.

Berdasarkan sekuens DNA hasil PCR, panjang keseluruhan amplikon kedua spesimen (F1 dan F2) adalah 829 bp (Gambar 2 dan Gambar 3, ditunjukkan oleh gambar panah berwarna merah). Panjangnya bukan tepat 831 bp seperti yang dirancang Matsuki $e t$ al. (1999) yang menjadi acuan untuk metode deteksi ini. Pada Gambar 2 dinotasikan untuk amplikon sampel F1 bahwa terdapat 20 nukleotida di awal sebagai primer maju (forward) yaitu BiLON-1 dan juga 20 nukleotida di akhir sebagai primer mundur (reverse) yaitu BiLON-2. Hal yang sama ditunjukkan oleh amplikon sampel F2 pada Gambar 3

Perbedaan panjang pita hasil PCR diagnostik dinilai sebagai sebuah kewajaran dengan pertimbangan bahwa referensi perancangan primer BiLON-1 dan BiLON-2 dari Matsuki et al. (1999) ini menggunakan sekuens 16S rRNA dari Escherichia coli (Neefs et al., 1991). Secara otomatis juga penomoran semua primer dalam artikel ini mengikuti satu acuan (E. coli) untuk memperkirakan panjang.

Dalam penelitian Moreno et al. (2002), Ward et al. (1998) dan Yatsunenko et al. (2012) menggambarkan bahwa perbandingan gen 16S rRNA, baik intraspesies maupun interspesies, akan terdapat variasi nukleotida dan variasi panjang dari specimen-spesimen yang ada. Variasi panjang nukleotida ini tidak berpengaruh untuk hasil diagnostik karena perbedaan dua nukleotida akan sulit dibedakan dalam elektroforesis gel agarosa. 


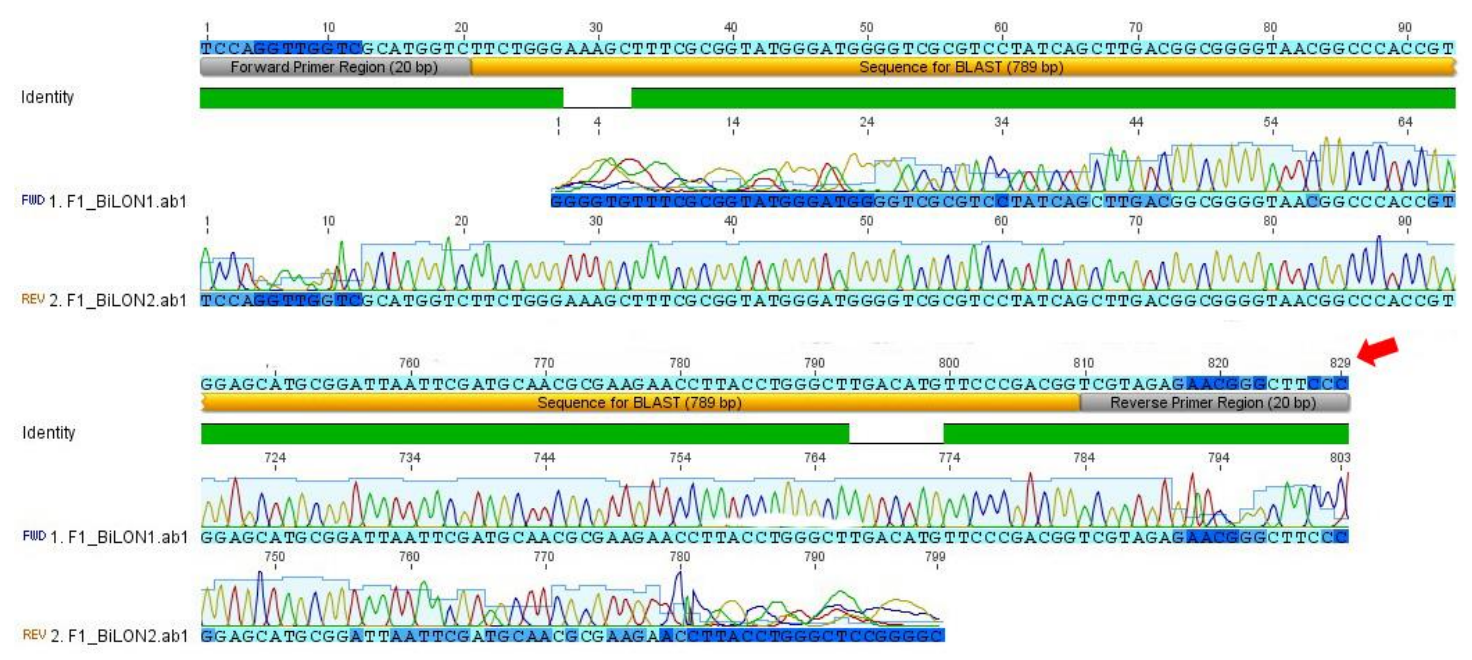

Gambar 2. Bagian ujung DNA 5' dan 3' dari penjajaran kromatogram Sampel F1

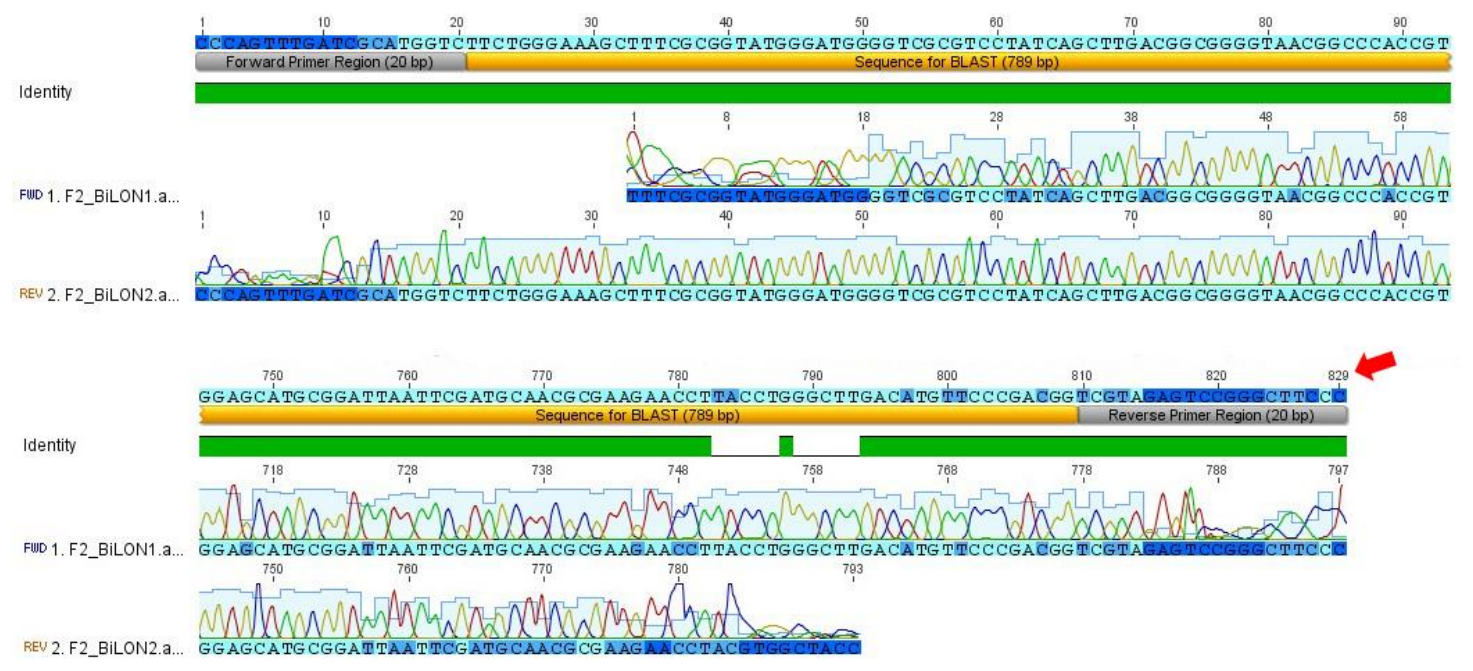

Gambar 3. Bagian ujung DNA 5' dan 3' dari penjajaran kromatogram Sampel F2

\section{Konfirmasi Sekuens Amplikon}

Kedua sampel yang digunakan dalam penelitian ini memiliki sekuens dengan tingkat kesamaan $100 \%$ atau keduanya identik (Gambar 4). Sekuens gen 16S rRNA sepanjang 789 bp dari masing-masing sampel penelitan yang dibandingkan satu sama lain, juga dibandingkan dengan seluruh sekuens yang ada dalam database GenBank NCBI (National Center for Biotechnology
Information). Ini digambarkan dalam Tabel 1, semua spesimen (hampir 100 spesimen) yang terdaftar dalam GenBank juga memiliki kemiripan $100 \%$ dengan sampel penelitian. Cakupan panjang DNA dari sekuens pembanding (query coverage) juga mencapai $100 \%$. Ini menandakan bahwa tingkat kesamaan (maximum identity) diperoleh lewat cakupan yang sebanding antara sampel dalam penelitian ini dengan spesimen pembanding di GenBank. 


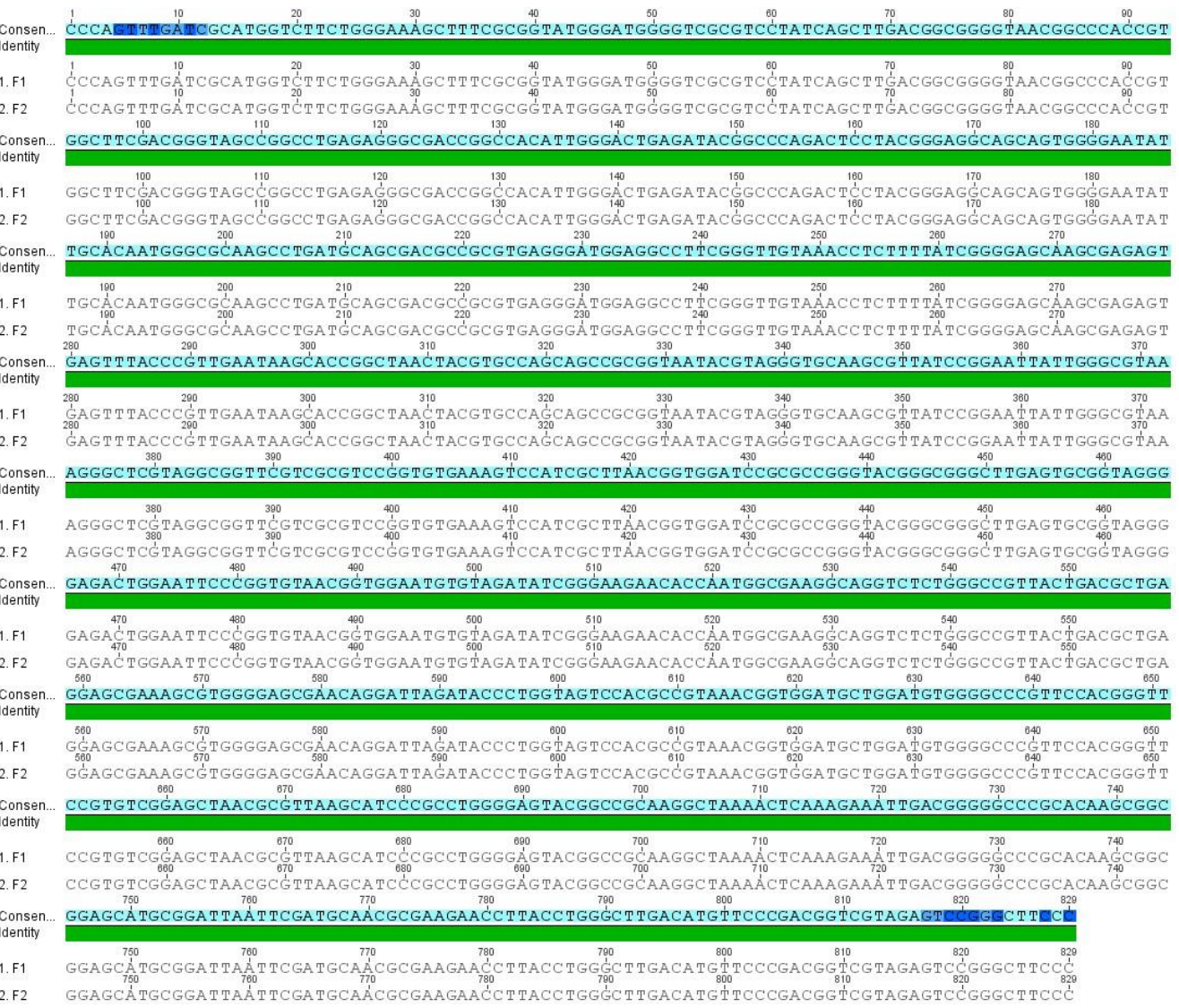

Gambar 4. Penjajaran hasil sekuensing spesimen F1 dan F2

Tabel 1. Identifikasi Sekuens Gen 16S rRNA Sampel Penelitian Hasil Diagnostik menggunakan Basic Local Alignment Search Tool (BLAST) tanggal 16 Januari 2020

\begin{tabular}{|c|c|c|c|c|c|}
\hline Nama Spesimen & $\begin{array}{c}\text { Query } \\
\text { Coverage }\end{array}$ & $\begin{array}{l}\text { Maximum } \\
\text { Identity }\end{array}$ & $\begin{array}{c}\text { Nomor } \\
\text { Aksesi } \\
\text { GenBank }\end{array}$ & $\begin{array}{c}\text { Sumber } \\
\text { Spesimen }\end{array}$ & Referensi \\
\hline $\begin{array}{l}\text { Bifidobacterium } \\
\text { longum subsp. } \\
\text { infantis }\end{array}$ & $100 \%$ & $100 \%$ & AP010890.1 & $\begin{array}{l}\text { Manusia dewasa } \\
\text { (Japan) }\end{array}$ & $\begin{array}{l}\text { Fukuda } \text { et al. } \\
\quad \text { (2011) }\end{array}$ \\
\hline $\begin{array}{l}\text { Bifidobacterium } \\
\text { longum subsp. } \\
\text { longum }\end{array}$ & $100 \%$ & $100 \%$ & HM009032.1 & $\begin{array}{l}\text { Manusia dewasa } \\
\text { (France) }\end{array}$ & $\begin{array}{l}\text { Messaoudi et al. } \\
\text { (2011) }\end{array}$ \\
\hline $\begin{array}{c}\text { Bifidobacterium } \\
\text { longum }\end{array}$ & $100 \%$ & $100 \%$ & СР043002.1 & $\begin{array}{l}\text { Manusia dewasa } \\
\text { (China) }\end{array}$ & Xiao et al. (2019) \\
\hline $\begin{array}{c}\text { Bifidobacterium } \\
\text { longum }\end{array}$ & $100 \%$ & $100 \%$ & JN004063.1 & $\begin{array}{l}\text { Carassius gibelio } \\
\text { (Czech Republic) }\end{array}$ & $\begin{array}{c}\text { Vlková et al. } \\
\text { (2012) }\end{array}$ \\
\hline $\begin{array}{c}\text { Bifidobacterium } \\
\text { longum }\end{array}$ & $100 \%$ & $100 \%$ & KU321257.1 & $\begin{array}{l}\text { Manusia dewasa } \\
\text { (Finland) }\end{array}$ & Priha et al. (2016) \\
\hline $\begin{array}{l}\text { Bifidobacterium } \\
\text { longum subsp. } \\
\text { longum }\end{array}$ & $100 \%$ & $100 \%$ & AB733110.1 & Bayi (Thailand) & $\begin{array}{c}\text { Uraipan dan } \\
\text { Hongpattarakere } \\
(2015)\end{array}$ \\
\hline $\begin{array}{c}\text { Bifidobacterium } \\
\text { longum }\end{array}$ & $100 \%$ & $100 \%$ & KY448279.1 & Bayi (India) & $\begin{array}{c}\text { Achi dan Halami } \\
(2019)\end{array}$ \\
\hline $\begin{array}{c}\text { Bifidobacterium } \\
\text { longum }\end{array}$ & $100 \%$ & $100 \%$ & MN372103.1 & Manusia (China) & Wei (2019) \\
\hline
\end{tabular}


Lewat perbandingan dengan BLAST, dapat dikonfirmasi bahwa pita DNA (dari dua sampel) hasil deteksi PCR adalah benar hanya mengamplifikasi gen targetnya yaitu gen $16 \mathrm{~S}$ rRNA dari B. longum saja. Di samping banyaknya bakteri yang terkandung dalam DNA total sampel feses, target deteksi yang dilakukan dengan kondisi PCR standar ini dinilai akurat.

\section{KESIMPULAN}

Deteksi bakteri B. longum melalui metode berbasis PCR berdasarkan Matsuki et al. (2019) mampu mendeteksi adanya bakteri ini dalam dua spesimen feses bayi di Kota Manado. Panjang DNA nyata hasil diagnostik ini adalah 829 bp, bukan 831 bp seperti yang diperoleh dari pengukuran dengan acuan DNA E. coli dalam publikasi. Keakuratan metode deteksi ini telah berhasil dikonfirmasi oleh hasil BLAST sebagai sekuens gen 16S rRNA dari B. longum dengan hasil identik dengan semua pembandingnya.

\section{DAFTAR PUSTAKA}

Achi, S.C. \& P.M. Halami. 2019. In Vitro Comparative Analysis of Probiotic and Functional Attributes of Indigenous Isolates of Bifidobacteria. Curr. Microbiol., 76: 304-311.

Altschul, S.F., W. Gish, W. Miller, E.W. Myers, \& D.J. Lipman. 1990. Basic Local Alignment Search Tool. Journal of Molecular Biology, 215(3): 403410.

Drummond A.J., B. Ashton, S. Buxton, M. Cheung, A. Cooper A, C. Duran, M. Field, J. Heled, M. Kearse, S. Markowitz, R. Moir, S. Stones-Havas, S. Sturrock, T. Thierer \& A. Wilson. 2012. Geneious v5.6. New Zealand.

Edgar, R.C. 2004. MUSCLE: Multiple Sequence Alignment with High Accuracy and High Throughput. Nucleic Acids Research, 32(5): 1792 1797.
Fukuda, S., H. Toh, K. Hase, K. Oshima, Y. Nakanishi, K. Yoshimura, T. Tobe, J.M. Clarke, D.L. Topping, T. Suzuki, T.D. Taylor, K. Itoh, J. Kikuchi, H. Morita, M. Hattori \& H. Ohno. 2011. Bifidobacteria can Protect from Enteropathogenic Infection through Production of Acetate. Nature, 469: 543-547.

Gavini, F., C. Cayuela, J. Antoine, C. Lecoq, B. Lefebvre, J. Membré \& C. Neut. 2001. Differences in the Distribution of Bifidobacterial and Enterobacterial Species in Human Faecal Microflora of Three Different (Children, Adults, Elderly) Age Groups. Microbial Ecology in Health and Disease, 13(1): 40-45.

Hernández-Rodríguez, D., A.A. VásquezAguilar, J.C. Serio-Silva, E. Rebollar, A. Azaola-Espinosa. 2018. Molecular Detection of Bifidobacterium spp. in Faeces of Black Howler Monkeys (Alouatta pigra). J. Med. Primatol. 48(2): 99-105.

Kolondam, B.J. 2015. Applying matK Gene for Identification of Liliopsida Plant Species from North Sulawesi through Bold Systems. International Journal of Applied Biology and Pharmaceutical Technology, 6(2): 242-245.

Matsuki, T., K. Watanabe, R. Tanaka, M. Fukuda \& H. Oyaizu. 1999. Distribution of Bifidobacterial Species in Human Intestinal Microflora Examined with 16S rRNA Genetargeted Species-specific primers. Appl. Environ. Microbiol. 65: 45064512.

Messaoudi, M., R. Lalonde, N. Violle, H. Javelot, D. Desor, A. Nejdi, J.F. Bisson, C. Rougeot, M. Pichelin \& J. Cazaubiel. 2011. Assessment of Psychotropic-like Properties of a Probiotic Formulation (Lactobacillus helveticus R0052 and Bifidobacterium longum R0175) in Rats and Human Subjects. British Journal of Nutrition, 105(5): 755-764. 
Moreno, C., J. Romero \& R.T. Espejo. 2002. Polymorphism in Repeated 16S rRNA Genes is a Common Property of Type Strains and Environmental Isolates of the Genus Vibrio. Microbiology, 148: 1233-1239.

Motherway, M.O.C. A. Zomer, S.C. Leahy, J. Reunanen, F. Bottacini, M. J. Claesson, F. O'Brien, K. Flynn, P. G. Casey, J.A.M. Munoz, B. Kearney, A.M. Houston, C. O'Mahony, D.G. Higgins, F. Shanahan, A. Palva, W.M. de Vos, G.F. Fitzgerald, M. Ventura, P.W. O'Toole \& D. van Sinderen. 2011. Functional Genome Analysis of Bifidobacterium breve UCC2003 Reveals Type IVb Tight Adherence (Tad) Pili as an Essential and Conserved Host-colonization Factor. Proc. Natl. Acad. Sci. USA, 108: 11217-11222.

Neefs, J.-M., Y.V. de Peer, P.D. Rijk, A. Goris \& R.D. Wachter. 1991. Compilation of Small Ribosomal Subunit RNA Sequence. Nucleic Acids Res., 19: 1987-2015.

Oki, K., T. Akiyama, K. Matsuda, A. Gawad, H. Makino, E. Ishikawa, K. Oishi, A. Kushiro \& Junji Fujimoto. 2018. Longterm Colonization Exceeding Six Years from early Infancy of Bifidobacterium longum subsp. longum in Human Gut. BMC Biology, 18(1): 209.

Priha, O., M. Raulio, J. Maukonen, A. Vehviläinen \& E. Storgårds. 2016. Bacterial Populations on Brewery Filling Hall Surfaces as Revealed by Next Generation Sequencing. Biofouling, 32(5): 571-581.

Tojo, R., A. Suárez, M.G. Clemente, C.G. de los Reyes-Gavilán, A. Margolles, M. Gueimonde \& P. Ruas-Madiedo. 2014. Intestinal Microbiota in Health and Disease: Role of Bifidobacteria in Gut Homeostasis. World J. Gastroenterol, 20: 15163-15176.
Turroni, F., E. Foroni, P. Pizzetti, V. Giubellini, A. Ribbera, P. Merusi, P. Cagnasso, B. Bizzarri, G. L. de'Angelis, F. Shanahan, D. van Sinderen, \& M. Ventura. 2009. Exploring the Diversity of the Bifidobacterial Population in the Human Intestinal Tract. Applied and Environmental Microbiology, 75(6): 1534-1545.

Temmerman, R., G. Huys \& J. Swings. 2004. Identification of Lactic Acid Bacteria: Culture-dependent and Cultureindependent Methods. Trends in Food Science \& Technology, 15(7): 348359.

Uraipan, S. \& T. Hongpattarakere. 2015. Antagonistic Characteristics Against Food-borne Pathogenic Bacteria of Lactic Acid Bacteria and Bifidobacteria Isolated from Feces of Healthy Thai Infants. Jundishapur J. Microbiol. 8(6): e18264.

Ventura, M., F. Turroni, M.O.C. Motherway, J. MacSharry \& D. van Sinderen. 2012. Host-microbe Interactions that Facilitate Gut Colonization by Commensal Bifidobacteria. Trends Microbiol. 20: 467-476.

Vlková, E., L. Kalous, V. Bunešová, K. Rylková, R. Světlíková \& V. Rada 2012. Occurrence of Bifidobacteria and Lactobacilli in Digestive Tract of Some Freshwater Fishes. Biologia, 67: 411-416.

Ward, D.M., M.J. Ferris, S.C. Nold \& M.M. Bateson. 1998. A Natural View of Microbial Biodiversity within Hot Spring Cyanobacterial Mat Communities. Microbiology and Molecular Biology Reviews, 62: 13531370.

Wei, L. 2019. Bifidobacterium longum strain ZJ1 16S ribosomal RNA gene, partial sequence. https://www.ncbi.nlm.nih. gov/nucleotide/MN372103.1 [diakses 21 Jan 2020].

Xiao, W., F. Lin, \& Y. Hou. 2019. The Complete Genome Sequence of Bifidobacterium longum BAMA-B05. https://www.ncbi.nlm.nih.gov/nucleoti de/CP043002.1 [diakses 21 Jan 2020]. 
Yatsunenko, T., F. Rey, M. Manary, I. Trehan, M.G. Dominguez-Bello, M. Contreras, M. Magris, G. Hidalgo, R.N. Baldassano, A.P. Anokhin, A.C. Heath, B. Warner, J. Reeder, J. Kuczynski, J.G. Caporaso, C.A. Lozupone, C. Lauber, J.C. Clemente, D. Knights, R. Knight \& J.I. Gordon. 2012. Human Gut Microbiome Viewed Across Age and Geography. Nature, 486: 222-227. 